\title{
Novos arranjos familiares e os múltiplos sentidos da adoção
}

\author{
New family samples and the multiple senses of adoption
}

\section{Alessandra de Andrade Rinaldi}

Professora Adjunta em Antropologia Social na UFRRJ. Possui graduação em Ciências Sociais pela Universidade Federal de Juiz de Fora (1994), mestrado em Antropologia pela Universidade Federal Fluminense (1997), doutorado em Saúde Coletiva pela Universidade do Estado do Rio de Janeiro (2004) e pós-doutorado em Antropologia Social pelo PPGAS/MN-UFRJ. Desenvolve pesquisas sobre gênero, violência, família e parentesco. Desde o ano de 2010 tem pesquisado a filiação adotiva.

\section{Resumo:}

O propósito do artigo é compreender as formas de governo das infâncias e juventudes por meio das políticas de adoção e seus efeitos sobre indivíduos ou casais que almejam ingressar com uma ação de adoção no município do Rio de Janeiro. Em termos empíricos, o artigo versa sobre pesquisa em habilitações e em processos de adoção de crianças e adolescentes que tramitaram entre 2000 e 2009 nas Varas da Infância, Juventude e do Idoso da comarca do Rio de Janeiro.

Palavras-chave: Adoção, Família, Relações Entre os Gêneros e Parentesco.

\section{Abstract:}

This article has the purpose to understand the forms of governance of children and youth through adoption policies and their effects on individuals or couples who seek to join an adoption action in the city of Rio de Janeiro. On empiric terms, this article is about the research on lawsuits for adoption that have been through, from 2000 until 2009, at the Children and Juvenile Courts in Rio de Janeiro.

Keywords: Adoption, Family, Relations between Gender and Parenthood. 


\section{INTRODUÇÃO}

Esse artigo é produto de pesquisas que desenvolvo desde 2009 no Rio de Janeiro ${ }^{1}$. O propósito desse trabalho é compreender as formas de governo das infâncias e juventudes (SCHUCH, 2009; 2009a; 2013) por meio das políticas de adoção e seus efeitos sobre indivíduos ou casais que almejam ingressar com uma ação de adoção no município do Rio de Janeiro.

Ao longo desses anos realizei pesquisa etnográfica suportada na produção de saberes sobre infâncias e relações de parentesco. À luz desses saberes pesquisei dispositivos legais, programas e políticas de ação voltadas à adoção, assim como práticas adotivas. Portanto, além de refletir acerca dos textos de leis, realizei pesquisa de campo em diversos contextos como nos ENAPAS (Encontro Nacional dos Grupos de Apoio à Adoção), nas Varas da Infância e da Juventude e em reuniões de Grupos de Apoio à Adoção (GAA). Analisei, ainda, documentos como processos de adoção e habilitações em adoção - procedimento administrativo obrigatório e prévio ao pleito - que tramitavam nas Varas da Infância, da Juventude e do Idoso da comarca do Rio de Janeiro (VIJI). Realizei entrevistas com integrantes do campo do direito e com pais adotivos e "pretendentes" à adoção.

Ao relacionar-me com pessoas desses cenários, com integrantes dessas entidades, com membros das Varas da Infância e da Juventude, com defensores públicos e com promotores de justiça da área da Infância e da Juventude, pais adotivos e "pretendentes à adoção", pude perceber que há controvérsias em torno dos sentidos e das práticas adotivas. Slogans tais como "adoção é um ato de amor", comuns nos encontros dos GAAs, remetem à ideia de que essa forma de parentalidade pode ser um "ato de solidariedade" (RINALDI, 2010). Tal sentido não é acatado com "bons olhos" por parte da equipe técnica das Varas da Infância e da Juventude (psicólogos e assistentes sociais), pa-

\footnotetext{
A genetização do parentesco, adoção e o impacto na questão da infância e adolescência no município do Rio de Janeiro, realizada com apoio da FAPERJ entre os anos de 2009 a 2011 e desdobrada em outra, Adoção em seus múltiplos sentidos, também apoiada pela FAPERJ entre 2012 e 2013. Atualmente desenvolvo o projeto Laços desfeitos, vínculos construídos e "socioafetividade": um estudo sobre valores morais e práticas legais no cenário da adoção no Rio de Janeiro, apoiada pelo CNPQ entre 2016 a 2018 (bolsa de produtividade) e pela FAPERJ (APQ1 E-26/010.002184/2015).
} 
ra a qual a adoção não deve ser um ato de caridade, mas a concretização do "desejo real de filiação".

Ao realizar pesquisas nos referidos contextos pude notar que importa a promoção da "nova cultura da adoção" (RINALDI, 2010). Ou seja, entre os integrantes do Poder Judiciário, os membros dos GAA e entidades ligadas à promoção dos direitos das crianças e dos adolescentes paira a ideia de que é relevante que os "pretendentes" (aqueles que almejam a adoção, já se habilitaram e/ou estão em processo de habilitação) possam ampliar os perfis dos filhos desejados. Para tanto, necessitam abrir a possibilidade de filiar os "dificilmente adotáveis" - meninos negros com mais de cinco anos de idade, com irmãos, portadores de algum tipo de necessidade especial ou problema de saúde ${ }^{2}$.

Além disso, encontrei o argumento de que mais importante do que satisfazer a vontade dos pretensos pais adotivos, a questão primordial é resolver o "problema" das crianças e adolescentes institucionalizadas no Brasil. Diferentes atores no cenário da Justiça da Infância e da Juventude e das práticas das adoções brasileiras, como integrantes do Poder Judiciário, da Defensoria Pública, do Ministério Público, membros de associações como o Instituto Brasileiro de Direito de Família (IDBFAM ${ }^{3}$ ), como o Instituto Brasileiro de Direito da Criança e do Adolescente (IBDCRIA - $\mathrm{ABMPT}^{4}$ ), de ONGs como a Terra dos Homens ${ }^{5}$, da Associação Nacional dos Grupos de Apoio à Adoção (ANGAAD), e pesquisadores do campo do Direito, como da Associação Bra-

2 Ver Cadastro Nacional de Adoção.

3 De acordo com o site do Instituto Brasileiro de Direito de Família - IBDFAM, "trata-se de uma entidade técnico-científica, sem fins lucrativos, que tem o objetivo de desenvolver e divulgar o conhecimento sobre o Direito das Famílias, além de atuar como força representativa nas demandas sociais que recorrem à Justiça” (http://www.ibdfam.org.br/conheca-o-ibdfam/historia). Acesso em: 05 jun. 2018.

4 De acordo com o site da instituição, "O IBDCRIA-ABMP tem objetivo de promover o aprimoramento da atuação dos diversos tipos de profissionais que atuem no Sistema de Garantias, fomentar avanços - ou impedir retrocessos - normativos no Direito da Criança e do Adolescente e estimular o debate público sobre a matéria." Disponível em: www.ibdcria-abmp org.br/noticia/direitos_da_crianca/instituto_brasileiro_de_direito_da_crianca_e_do_adolescente_ibdcriaabmp.html. Acesso em: 12 maio 2017.

5 Terra dos Homens é uma organização sem fins lucrativos, fundada por Claudia Cabral, psicóloga atuante na área social desde 1977 e sensibilizada com o número de crianças afastadas de suas famílias, vivendo em abrigos. Trata-se de uma entidade "certificada como entidade de Utilidade Pública Estadual e Beneficente de Assistência Social”. Disponível em: http://www.terradoshomens.org.br/pt-BR/histories. Acesso em: 4 maio 2018 . 
sileira de Jurimetria $(\mathrm{ABJ})^{6}$, dentre outros, trataram do tema da institucionalização. Vale ressaltar que a ideia de que adoção é política pública não é aceita sem controvérsias, sobretudo para o setor técnico das Varas, que a compreende como concretização de um projeto parental.

Em face deste "problema" alguns interlocutores centraram-se em críticas à Lei $12.010 / 09^{7}$, que dispôs sobre adoção até 2017, por meio de alteração na Lei 8.069 de 1990 - Estatuto da Criança e do adolescente (ECA). Ao alterar esse Estatuto, de acordo com Silva e Arpini (2013), a Lei determinou que infantes e jovens não ficassem em "instituições de acolhimento" por mais de dois anos, devendo ter a situação do "vínculo familiar" avaliada por equipe interprofissional dessas entidades a cada seis meses, visando, assim, à "reintegração" às suas "famílias de origem".

Importante ponderar que em período anterior, durante o fim dos anos de 1980, com a promulgação da Constituição Federal de 1988 e do ECA, o cenário legislativo brasileiro consolidou, em termos formais, a importância da manutenção de infantes e jovens em suas famílias de nascimento. Tal fato produziu como consequência a ideia de que a adoção seria um encaminhamento a ser tomado pela Justiça da infância e da Juventude, esgotadas todas as possibilidades de "reintegração familiar".

De acordo com Rizzini e Rizzini (2013, p. 127), esses dispositivos materializaram a ruptura com a ideia, presente no Código de Menores de $1979^{8}$, baseada na "doutrina da situação irregular", de que famílias de camadas po-

\footnotetext{
6 Segundo consta nesse material, a ABJ "é uma entidade sem fins lucrativos, formada por pesquisadores do Direito e da matemática, que tem por objetivo investigar e incentivar a aplicação da estatística e da probabilidade no estudo do Direito e de suas instituições" (MENDES, 2015, p. 21).

7 Esta lei foi revogada em novembro de 2017 e substituída pela Lei 13.509/17, que dispõe sobre adoção e altera a Lei 8.069/90 (Estatuto da Criança e do Adolescente). O novo dispositivo versa, dentre outras coisas, a respeito da possibilidade de "entrega voluntária de um filho" por intermédio da Justiça da Infância e da Juventude; delimita prazos para a "destituição do poder familiar" e para o término do processo de adoção (120 dias prorrogáveis pelo mesmo prazo), além de priorizar, na fila da adoção, os "postulantes" que querem filiar grupos de irmãos e/ou adolescentes com algum tipo de necessidade específica de saúde.

8 De acordo com Rinaldo e Barreto (2009, p. 20), "Assim como no primeiro, no segundo Código de Menores, datado de 1979, estava presente a ideia subjacente de discriminação de uma parte da população infantil, ou seja, a da parcela pobre".

9 De acordo com Rinaldi e Barreto (2009), doutrina fundada num modelo policialesco que partia da visão de que crianças pobres estariam em situação de "desvio social".
} 
pulares seriam incapazes de cuidar de seus filhos ${ }^{10}$. Sendo assim, é possível aventar a hipótese de que esses dispositivos materializam a crítica de que essas famílias seriam incapazes de cuidar de seus filhos.

Ao longo dos últimos onze anos aplicou-se a Lei 12.010/09. No entanto, diferentes entidades debateram sua efetividade, assim como a necessidade de ser ou não reformada. Foi revogada e o ECA, novamente alterado a partir da aprovação do Projeto de Lei da Câmara (PLC) 101/2017, de autoria do deputado Augusto Coutinho (SF-PE). Tal Projeto resultou de uma consulta pública feita pelo Conselho Nacional da Criança e do Adolescente em 2016 sobre a necessidade de reforma da Lei 12.010/09 e teve rápida tramitação no senado, após chegar à Casa em setembro de 2017.

Apesar da alteração desse dispositivo, é importante ressaltar que grande parte do material coletado nas pesquisas realizadas tomou como marco a promulgação da Lei 12.010/09. Para o presente texto, a ideia é chegar aos motivos que levam pessoas ou casais à filiação adotiva a partir da análise de documentos tais como as ações de adoção e as habilitações - procedimento administrativo obrigatório e prévio ao pleito - que tramitavam nas Varas da Infância, da Juventude e do Idoso da comarca do Rio de Janeiro (VIJI).

Até recentemente existiam três varas no Rio de Janeiro: Vara de Infância Juventude e do Idoso da Comarca da Capital (VIJI), Vara da Infância da Juventude e do Idoso ( $\left.1^{\circ} \mathrm{VIJI}\right)$ - regional de Madureira - e Vara da Infância da Juventude e do Idoso $\left(2^{\circ} \mathrm{VIJI}\right)$ - regional de Santa Cruz. Atualmente existem quatro: $1^{\text {a }}$ Vara da Infância da Juventude e do Idoso da Comarca da Capital, $2^{\text {a }}$ Vara da Infância da Juventude e do Idoso da Comarca da Capital, Vara da Infância da Juventude e do Idoso - regional de Madureira - e Vara da Infância da Juventude e do Idoso - regional de Campo Grande ${ }^{11}$.

Os dados que abordo dizem respeito ao levantamento realizado nas regionais de Santa Cruz e de Madureira. Investiguei processos iniciados a partir dos

\footnotetext{
10 Para reflexões críticas ver Fonseca (2009; 2012).

${ }_{11}$ Vara criada há pouco tempo, abrange os processos que tramitaram na extinta Vara da Infância da Juventude e do Idoso, regional de Santa Cruz.
} 
anos de 2000 até o momento atual. No entanto, analisarei os que tramitaram entre 2000 a 2009, ano da publicação da Lei 12.010/09, que reformou o ECA.

A escolha do ano inicial deveu-se às limitações impostas pelo campo. Uma vez que só em 2018 obtive autorização para a realização da pesquisa nas Varas da Comarca da Capital, o levantamento ateve-se aos dados contidos nas regionais. Como foram criadas em 2006, o material diria respeito a este período em diante. No entanto, como houve redistribuição de processos em andamento da VIJI da Comarca da Capital para aquelas em função da jurisdição territorial, essas varas contemplaram ações abertas a partir de 2000 e, por esse motivo, obtive acesso aos documentos iniciados a partir dessa data.

Ao todo, coletei 99 processos e 67 habilitações em adoção ${ }^{12}$. Como dito, os dados dizem respeito às Varas regionais de Madureira e de Santa Cruz. Quanto ao perfil socioeconômico dos envolvidos nos processos, pode-se afirmar que são predominantemente oriundos das camadas populares urbanas ${ }^{13}$. Isso se deve ao fato de os documentos pesquisados serem, em grande parte, relativos às regiões administrativas que correspondem às áreas ocupadas por uma população de baixa renda.

\section{METODOLOGIA}

À luz de Muzzopapa e Villalta (2011), compreendo os autos processuais como peças resultantes do fluxo da burocracia das práticas da justiça da infância e da juventude, produzidas por diversos atores como advogados, promotores de justiça, psicólogos, assistentes sociais, juízes, pais adotivos, famílias "doadoras" (cujos filhos serão adotados). Inspirada também em Vianna (2002), entendo os processos de adoção e as habilitações como um conjunto de relatos convertidos em "depoimentos", escritos por um mecanismo de

\footnotetext{
${ }^{12}$ Uma vez que tramitam em "segredo de justiça", opto por não citá-los nas referências com o intuito de resguardar a identidade dos envolvidos. Pela mesma razão, ao realizar a análise qualitativa uso nomes fictícios e, por vezes, misturo histórias semelhantes.

${ }^{13}$ Segundo Couto (2005, p. 198), "a categoria famílias populares urbanas [...] se refere de forma genérica àqueles que são destituídos do que, na nossa sociedade, confere poder, riqueza e prestígio".
} 
controle burocrático e de construção de afirmação de autoridade fundamentais para a produção de uma decisão judicial. Vislumbro esse material como resultado de um confronto de posições de autoridade entre os que depõem e os que são responsáveis por traduzir as falas em termos da universalidade jurídica. Dessa forma, uma vez demarcado o poder desses últimos, o que se tem como resultado e/ou depoimento é algo que foi produzido sob condições de constrangimento (VIANNA, 2002).

Levo em conta que não só os profissionais que compõem os autos possuem "voz" ao longo do fluxo processual: "pretendentes" à adoção, pais adotivos, assim como pais de nascimento, também se manifestam acerca das situações pelas quais estão sendo avaliados. Por essa razão, parto do pressuposto de que as pessoas envolvidas nesse fluxo, ao produzirem seus relatórios, tomarem suas decisões e conduzirem os caminhos processuais, levam em conta as versões morais contidas nos depoimentos dos "pretendentes" e/ou dos processados (genitores).

Acredito, portanto, que os responsáveis por acolher, avaliar, analisar e julgar "pretendentes" e esses pais e mães não produzem suas considerações sobre o fato legal exclusivamente, mas antes alargam suas "sensibilidades" à luz de moralidades a respeito do que consideram do que os envolvidos nas ações entendem por famílias, afeto e projetos parentais. Partindo dessas considerações, investigo os autos a fim de perceber como tanto os oficiantes da justiça quanto os litigantes produzem e reproduzem visões sobre o que leva pessoas e casais à filiação "socioafetiva".

\section{A COMPOSIÇÃO DO MATERIAL TRABALHADO: A HABILITAÇÃO E O PROCESSO DE ADOÇÃO}

A habilitação é um procedimento administrativo que, após a promulgação da Lei 12.010/2009, conhecida como a Nova Lei da Adoção, foi transformada em etapa obrigatória para uma adoção, permanecendo nos dias atuais na vigência da Lei 13.509/17. Trata-se de procedimento inicia- 
do com uma petição, entregue em cartório da Vara de Infância, da Juventude e do Idoso, pelo interessado, junto com certidões negativas de feitos cíveis e criminais e atestado de sanidade física e mental ${ }^{14}$. Depois de depositada, essa petição será remetida à equipe técnica (psicólogos e assistentes sociais das Varas) que, de acordo com as determinações administrativas locais, conduzirá a participação dos requerentes em programas de capacitação à paternidade adotiva ${ }^{15}$.

Posteriormente, a mesma equipe dará início ao trabalho pericial, feito por meio de entrevistas, de visitas domiciliares, de produção de parecer social e psicológico remetido ao Ministério Público e, posteriormente, ao Juiz da Vara. Todo este procedimento é composto por informações sobre os requerentes, dados sobre a criança e/ou adolescente pretendidos, relatórios psicossociais, ofício do Ministério Público e sentença do Juiz.

Mesmo antes da Lei 12.010/2009, de acordo com o art. 50 do Estatuto da Criança e do Adolescente era prevista a obrigatoriedade da inscrição de habilitados à adoção em cadastros locais e nacionais sem, entretanto, existir uma padronização nacional para tal procedimento ${ }^{16}$. A modificação foi efetuada em 2008 com a criação do Cadastro Nacional de Adoção (CNA), ferramenta construída, de acordo com a visão do campo pesquisado, para otimizar procedimentos, tornando indivíduos aptos a adotarem em qualquer comarca ${ }^{17}$. O Cadastro foi desenvolvido pelo Conselho Nacional de Justiça (CNJ) com o intuito de cruzar dados sobre crianças e adolescentes aptos a serem adotados e sobre o perfil desejado pelos pretendentes. Além disso, o CNA foi organizado com a proposta de tornar mais célere o trâmite legal.

\footnotetext{
${ }^{14}$ Em caso de petição feita por um casal, basta a presença de um dos parceiros desde que todos os documentos estejam duplamente assinados e atestados.

15 A partir da Lei 13.509/17, essa capacitação é feita através da participação em cursos preparatórios e em encontros de Grupos de Apoio à Adoção conveniados com as Varas.

${ }^{16}$ Segundo Bittencourt, "estes cadastros seguem o princípio da isonomia, usando a ordem cronológica de inscrição para definir a prevalência de um inscrito sobre os demais, quando interessados no mesmo perfil de criança” (BITTENCOURT, 2010, p. 130).

17 Segundo o Guia do usuário, do Conselho Nacional de Justiça, “1.4. O Cadastro Nacional de Adoção estabelece originalmente como critério de preferência a data da sentença de habilitação. Contudo, fica assegurada ao juiz a liberdade para, dentre os habilitados, escolher aquele que, na sua concepção, for o mais indicado para o caso concreto". Cadastro Nacional de Adoção. Guia do usuário. Maio de 2009, p. 4. Disponível em: http://bit.ly/2GSomHT. Acesso em: 15 mai. 2010.
} 
O processo de adoção é decorrente de um procedimento jurídico que transfere todos os direitos dos "pais biológicos" para uma "família substituta". Entretanto, para que haja essa transferência, há a necessidade da habilitação prévia. Posto isso, é possível que este procedimento jurídico seja iniciado por uma pessoa sozinha, modalidade denominada de "adoção monoparental" ou por um casal.

Todavia, a adoção pode acontecer sem o candidato ter passado por esse procedimento administrativo. Por exemplo, isso ocorre quando alguém, na guarda de uma criança ou de um adolescente que lhe foi entregue ainda recém-nascido pelos "genitores", vai ao Judiciário e solicita a abertura da ação. Nesses casos, segundo Abreu (2002), as ações propostas são denominadas pelos juristas brasileiros de intuitu personae.

Este percurso adotivo - guarda irregular e posterior ação de adoção - é tratado atualmente pelo legislativo e pelo Judiciário como um problema. Isso se deve ao fato de como esses poderes entendem o procedimento. Acredita-se que toda a trajetória, desde a decisão por esta filiação até o encontro com o filho adotivo, tem de ser regulada pelo Judiciário de forma a evitar favorecimentos financeiros às "famílias doadoras".

Tal assertiva deve-se à constatação (cf. FONSECA, 2013, p. 270) de que o universo adotivo é composto por uma enorme desigualdade social e econômica entre pais adotivos e famílias doadoras, sendo as primeiras mais abastadas do que as segundas. Em face disso, o pressuposto é de que "genitores" possam "tirar vantagens", transformando as suas proles em bens vendáveis no mercado adotivo. Uma vez que em nossa sociedade dinheiro e afeto são compreendidos como excludentes (cf. ZELIZER, 1994 apud FONSECA, 2013), o domínio da adoção, que é o da família e dos afetos, ao ser invadido pela lógica do dinheiro é tornado poluído. Dessa forma, "genitores" ofertando seus filhos e "pretendentes" supostamente "comprando-os" (por meio do auxílio ao parto e/ou ajuda financeira à família doadora) seria a materialização de uma prática que corromperia a nova "família", posto que transformaria a criança esperada em "objeto". 
Retornando às diferentes maneiras de um processo de adoção ser aberto, nota-se que esse pode ser ajuizado por pessoas que desejam perfilhar os filhos(as) de seus parceiros. Essa modalidade de adoção pode ocorrer em dois contextos familiares distintos: em primeiro lugar, quando uma nova família começa com a mãe, sua prole e seu/sua parceiro; em segundo lugar, quando outro núcleo conjugal se constitui por meio do pai, sua prole e sua/seu nova parceira (o). Dessas reestruturações familiares originam as demandas pela nova filiação tanto pelo parceiro da mãe, quanto pela companheira do pai ${ }^{18}$.

Esta prática é considerada intuitu personae. Sendo assim, dispensa a intermediação prévia do Poder Judiciário. Esta é uma forma de filiação denominada adoção unilateral e, segundo o universo jurídico brasileiro, possui um caráter híbrido porque permite que se substitua somente um dos genitores e sua respectiva ascendência. Conhecida como semiplena, é voltada para estruturas familiares constituídas por um dos "genitores" e sua prole. Este tipo de ação pode ocorrer, segundo Moura (2011), quando o infante ou jovem foi registrado por apenas uma pessoa. Caso este autorize, seu(sua) parceiro(a) poderá ajuizar esta ação. Acontece também quando a criança ou adolescente possui o registro civil de ambos os genitores. Basta a anuência de um deles para ocorrer a destituição do poder familiar do outro e iniciar-se, assim, a ação de adoção. É possível que surja também em decorrência de falecimento de um dos pais.

Em todos estes casos citados, em termos de composição, é de fundamental importância a petição inicial, feita por defensores públicos ou advogados privados, que representam os requerentes, argumentando sobre a necessidade da causa. Serão os fundamentos dos fatos, de acordo com Bittencourt (2010), que darão o caráter contencioso, promovendo a possibilidade de os genitores se manifestarem, caso discordem do feito. O que não ocorrerá nos casos de pais falecidos ou com poder familiar suspenso ou destituído. Já o Ministério

\footnotetext{
${ }_{18}$ Em razão da decisão do Supremo Tribunal Federal (STF), que em 2011 reconheceu a união estável de pessoas do mesmo sexo, ações de adoções unilaterais começaram a ser ajuizadas por pessoa de declarada orientação homossexual. Até esta data, de acordo com o art. 39, $\$ 2^{\circ}$ da Lei 12.010/09, para adoção conjunta era indispensável que os adotantes fossem casados civilmente ou mantivessem união estável comprovada. Por conseguinte, pares homossexuais encontravam dificuldades de realizar um projeto de filiação conjunta. Em razão disso, indivíduos que viviam uma união consensual decidiam adotar sozinhos. Entretanto, uma vez reconhecidos legalmente como casais, alguns parceiros gays e lésbicas escolheram adotar os filhos adotivos e/ou biológicos de seus respectivos companheiros.
} 
Público, no curso deste procedimento jurídico, figura no lugar de representante da lei com o intuito de garantir o princípio constitucional do "melhor interesse da criança e do adolescente".

\section{SENTIDOS DE PARENTESCOS, SOFRIMENTOS E DESEJO DE FILIAÇÃO ${ }^{19}$}

A compreensão ocidental do significado de parentesco e de suas implicações sociais e jurídicas não está isenta de historicidade, tampouco é passível de ser apreendida como uma verdade absoluta e inquestionável. Prova disso são as considerações sobre o impacto que as ciências biomédicas tiveram ao final do século XX, não só na composição de novas relações de parentalidade, mas também na maneira como os campos de produção eruditos passaram a conceber família e parentesco.

Segundo Fonseca (2004), a popularização da pílula anticoncepcional na década de 1960 e sua consequente promoção de ruptura entre sexualidade/ reprodução, as novas tecnologias reprodutivas ${ }^{20} \mathrm{e}$ a possibilidade de mudança de gênero foram fatos que contribuíram para a alteração da visão ocidental sobre laços biológicos, família e parentesco. Nesse contexto, a biologia deixa de ser vista como um dado bruto ou anterior à cultura, ao mesmo tempo em que não é mais entendida como uma força que opera a partir de uma suposta natureza dada ou fixa.

No entanto, segundo a mesma autora, esse cenário é circunscrito por um paradoxo no que diz respeito à visão a respeito de elos biológicos e parentesco. Ao mesmo tempo em que aumentam as intervenções sobre o corpo e as per-

\footnotetext{
${ }_{19}$ Os nomes e alguns elementos das histórias são ficcionais para que o segredo de justiça seja resguardado.

20 "Novas tecnologias reprodutivas ou técnicas de reprodução assistida são procedimentos da medicina que substituem o ato sexual na concepção. As mais conhecidas são a inseminação artificial e a fertilização in vitro (bebê de proveta). Tais técnicas supõem a manipulação de pelo menos um gameta fora do corpo. $\mathrm{Na}$ inseminação artificial, em contexto de medicalização, faz-se estimulação ovariana leve, depois sêmen tratado é introduzido através do colo do útero no período fértil. Na fertilização in vitro, ou FIV, após um período de estimulação dos ovários com altas doses de medicamentos hormonais, coletam-se óvulos que, por sua vez, são unidos em laboratório com sêmen tratado. O embrião é transferido para o útero ou congelado." (LUNA, 2005, p. 394).
} 
cepções acerca da importância das ações humanas na constituição da parentalidade, ocorre a disseminação da ideia de que parentesco é biológico/genético.

De acordo com Sarah Franklin (2001, p. 302), os “fatos biológicos", como "naturezas artificiais construídas", impactam as relações de parentesco, possibilitando a criação ou ruptura de conexões entre as pessoas ${ }^{21}$. Isso porque, de acordo com a antropóloga Marilyn Strathern (2015), as informações genéticas sobre as pessoas produzem não apenas dados a respeito da origem, mas geram sentidos de identidades, noções de pertencimentos e de "propriedades". Dessa forma, podem criar ou desfazer relações, dependendo dos espaços existentes na vida dos indivíduos para acomodar ou limitar as forças constitutivas das informações de parentesco (CARSTEN, 2007, p. 419). É nesse cenário que os exames de DNA surgem como mecanismos científicos de demonstração empírica desta assertiva (FONSECA, 2004), não apenas criando relações, mas desfazendo conexões de parentesco já estabelecidas por meio da informação de que, por exemplo, aquele a que se reconhecia como filho não o é, posto que não contem as mesmas origens genéticas.

Assim sendo, todos esses fenômenos puderam provocar transformações nas relações entre as pessoas. A mecanização da reprodução humana possibilitou, por exemplo, que pessoas "inférteis" e mulheres virgens exercessem a parentalidade (STRATHERN, 1995) ${ }^{22}$. A assistência médica tornou a vontade de ter filhos uma exigência fundamental a ser satisfeita por meio de terapias reprodutivas, que reiteram o discurso do "sangue" ou da conexão biogenética nas práticas do parentesco.

Entretanto, no contexto pesquisado, encontrei nos documentos de adoção e de habilitação argumentos que não se pautavam exclusivamente no idioma biogenético quando a questão é explicar o que levava à busca por um filho adotivo. Ela pode ser uma tentativa de "resolver" o problema de infertilidade. No entanto, pode, mais do que isso, significar uma ma-

${ }^{21}$ O autor aborda o biológico como um sistema cultural por meio do qual formulamos sentidos de parentesco.

${ }^{22}$ No artigo "Necessidade de pais, necessidade de mães" (1995), a antróloga Marilyn Strathern reflete sobre os efeitos sociais das demandas de mulheres virgens pelo uso de técnicas de reprodução assistida na Grã-Bretanha do final dos anos de 1990. 
neira de construir relações de parentesco não suportadas na configuração biogenética. David Schneider (1980), ao estudar o sistema de parentesco nos Estados Unidos, aborda a concomitância entre dois modos básicos de constituí-lo: como substância biogenética e como código de conduta. É possível perceber essa repetição simbólica em nossa sociedade. Concebemos parentesco por um lado como produto dos laços de "sangue" e, por outro, como resultado do cuidado, da criação, do reconhecimento e do afeto proveniente do convívio social entre pessoas.

Ambas as visões emergem dos documentos analisados. A ideia de que parentesco e filiação podem ser criados por meio de relações sociais aparece em algumas ações de adoção. Ao longo da pesquisa pude perceber argumentos dessa ordem na habilitação proposta, em 2008, pelo casal Mauro e Camila. O primeiro, um militar de carreira, a segunda, uma dona de casa. Casados há mais de dez anos, com uma filha de nove anos, decidiram pela adoção. De acordo com trechos do relatório produzido pela equipe técnica da Vara (psicólogos e assistentes sociais), ambos não apresentaram restrições reprodutivas. Segundo a exposição de motivos do que levaria à habilitação, produzida pelo advogado do casal:

A requerente não tem qualquer impossibilidade em gestar, apenas não deseja mais enfrentar as primeiras etapas necessárias aos cuidados infantis. Fora que a requerente não deseja enfrentar nova gravidez. E foi o pedido da filha, de 9 anos, que ensejou o desejo de adotar, que se traduz no desejo de dar uma irmã para a filha.

É possível perceber a presença do pressuposto de que o que moveria um casal à adoção seria algum "problema reprodutivo". Em resposta dada por meio do advogado Camila, tomada como a voz do casal, manifesta que a razão que os leva à VIJI é a "vontade de dar uma irmã para sua filha". No caso, desejam adotar uma menina com até sete anos de idade. Nesse sentido, demonstra um alargamento das possibilidades de produção de conexões de parentesco que ultrapassam a biogenética. A partir da possibilidade da criação de laços entre as meninas e entre a criança pretendida e o casal, essa demandante transforma, 
nos termos de Ingvesson (2007, p. 130), um relacionamento entendido "como fundamentado no sangue" em uma conexão pautada na escolha adotiva.

Ao escolherem ter uma filha que não seja produto de suas substâncias biogenéticas, esse casal, representado pela voz de Camila, alarga a concepção de parentesco. Ao mesmo tempo, transformam a criança pretendida em uma dádiva (MAUSS, 1988) ofertada à filha existente.

Há, no entanto, posições opostas. Existem "pretendentes" que alocam o Poder Judiciário no lugar de uma espécie de clínica de reprodução assistida, cujo objetivo é lhes fornecer filhos. Isso ocorre em alguns processos e habilitações dentro dos quais "problemas reprodutivos" são construídos como um móvel para a ação. Nesses casos, os demandantes alegam a "vontade de ter um filho do próprio sangue".

Estas situações podem conduzir pessoas às Varas de Infância, da Juventude e do Idoso (VIJI) em busca do filho desejado. Neste cenário, a filiação "socioafetiva" pode significar uma espécie de substituição ao filho biológico idealizado. Uma vez que os "pretendentes" à adoção, assim como os pais adotivos, narram essas razões ao longo do processo diversas vezes (para os advogados/ defensores, psicólogos, assistentes sociais, promotores, juízes), suas narrativas são avaliadas, sobretudo pela equipe técnica da Vara da Infância e da Juventude.

Esses profissionais incorporam em suas práticas uma política de proteção à infância e à juventude, significando dizer que consideram em primeiro plano o "melhor interesse da criança e do adolescente" e, em menor proporção, a vontade do "pretendente" de ter um filho ${ }^{23}$. Portanto, aqueles que demandam a adoção devem ser avaliados à luz dessas políticas protetivas.

Os demandantes ("pretendentes" e pais adotivos), por sua vez, ao produzirem as razões que os levam à adoção, consideram, além dessa política, o fato de que estão sendo avaliados quanto à capacidade de serem pais e mães por adoção. Dessa forma, ao deporem frente aos representantes da Justiça da Infância e da Juventude, produzem uma positividade de si mesmo e narram suas trajetórias até a decisão pela chegada às Varas da Infância e da Juventude.

\footnotetext{
${ }^{23}$ Algo semelhante acontece na prática adotiva canadense analisada pela antropóloga Françoise Oullette (2000).
} 
A fim de serem contemplados com o benefício da habilitação ou da sentença de adoção, dedicam-se a demarcar o esforço que tiveram e as etapas de sofrimento por que passaram até chegar à busca pela adoçã $0^{24}$. Alguns pares relatam que sofreram muito até chegar às VIJI. Contam sobre as perdas gestacionais e financeiras em função de gastos com tratamentos de infertilidade. Relatam a frustração por não ter continuado o percurso da reprodução assistida em razão dos custos financeiros. Outros, ao contrário, descrevem que não desejam mais a exposição a estes tratamentos ${ }^{25}$, não só em razão dos gastos "infrutíferos", mas em face das frustrações por não conseguirem a gravidez desejada.

Essas narrativas concretizam-se na habilitação do casal Horácio e Pâmela. O primeiro trabalha como pintor de carros e a segunda, como secretária. Casados há sete anos, fizeram uso de técnicas de reprodução assistida. Dessa resultou uma gestação que, além de não ter evoluído, levou Pâmela a correr risco de morte. De acordo com um trecho do relatório psicossocial da habilitação do casal, sentenciados favoravelmente, "o casal mantém um relacionamento próximo, afetuoso e companheiro. A adoção foi decidida após algumas tentativas frustradas de Fernanda engravidar, tendo ela corrido risco de vida na última gravidez interrompida".

É possível notar que a narrativa, traduzida em termos do relatório técnico, visa ressaltar seus dramas, o percurso de dor e de sofrimento. De forma análoga ao narrado por Didier Fassin (2014) sobre a forma como imigrantes em solo francês vêm lidando com a burocracia estatal francesa, os "pretendentes" à adoção, assim como aqueles imigrantes, usam como recurso a exaltação de seu sofrimento. Talvez isso se deva ao fato de que as moralidades da burocracia das Varas da Infância e da Juventude carioca, assim como as práticas do Estado francês, estejam organizadas por uma política da compaixão que tende a valorizar a dimensão dos corpos e pessoas em sofrimento.

\footnotetext{
${ }^{24}$ Algo análogo é descrito pelas antropólogas Jeanette Edward e Marilyn Strathern (2000) ao narrarem arranjos de parentescos ocorrido no norte da Inglaterra que fizeram uso da "mãe de aluguel". As pessoas que fizeram uso desse recurso são vistas de forma positiva pelo "esforço" que tiveram ao buscar as clínicas de apoio (2000, p. 149).

25 Ver Strathern (2015).
} 
Além disso, as antropólogas Carolina Ciordia e Malene Russo (2013), ao pesquisarem as políticas de gestão das famílias e das infâncias na Argentina, ressaltam o quanto essas se materializam em práticas marcadas por sensibilidades jurídicas pautadas na ideia de que famílias são lócus dos "afetos, das emoções e dos sentimentos”. Salvo diferenças entre Brasil e Argentina, é possível ressaltar pontos de contatos, posto que a gestão da infância e da juventude é invadida pela linguagem dos "sentimentos". Sendo assim, ressaltar que não são apenas mais "um caso" de adoção, mas são casais, pessoas, famílias com histórias de sofrimento são caminhos produtivos para aqueles que desejam filhos por via adotiva.

\section{PARENTESCO NÃO EXCLUSIVO, DÁDIVAS E DEMANDAS POR ADOÇÃO}

A adoção no Brasil é efetuada de forma "plena", ou seja, rompendo os vínculos legais e supostamente os afetivos com a família de origem. No entanto, nossa legislação contempla, em casos de adoção unilateral, que esta seja semiplena, uma vez que permite que se substitua somente um dos genitores e sua respectiva ascendência.

De acordo com a antropóloga Françoise Ouellette (2000), as legislações que adotam essa perspectiva incorporam em seu escopo o ideal ocidental de família consanguínea que estabelece um modelo exclusivo de filiação. Segundo a pesquisadora (2000, p. 51, tradução livre), "esse modelo genealógico de reprodução estabelece que um indivíduo não possa ser filho de mais de um pai e de uma mãe". Sendo assim, a adoção plena perpetua, nos termos da lei, essa simbólica.

A antropóloga Claudia Fonseca, em suas pesquisas sobre famílias de camadas populares no Rio Grande do Sul, vem ressaltando o grande número de crianças e jovens que passam parte de suas vidas "circulando" e sendo cuidados em casas que não a de seus pais de nascimento. A partir de uma perspectiva comparativa com outras regiões do país, a antropóloga nos convoca a 
pensar esses arranjos não como "colapso dos valores tradicionais", mas como "uma estrutura básica de organização de parentesco [...] vinculada a uma cultura popular urbana" (FONSECA,1993, p. 116).

Dessa forma, é importante ressaltar que esse modelo organiza-se de forma distinta daquele pautado na exclusividade de filiação e de parentalidade. Entre os dados analisados, pude encontrar muitas ações de adoção propostas por pessoas ou famílias de camadas populares cariocas que viviam esses arranjos não exclusivos de parentesco. Quase a metade dos 99 processos de adoção coletados foi proposta por requerentes que buscavam filiar infantes e jovens que lhes foram entregues pelos pais de nascimento, uma vez que eram padrinhos, amigos da família de origem, vizinhos, parentes ou mesmo pessoas desconhecidas. Esses pais adotivos não escolheram originalmente tornar esses meninos e meninas em seus filhos. Receberam-lhes em suas casas porque suas mães os deixaram; porque lhes foi solicitada ajuda nos cuidados com o infante ou por saberem que eram vítimas de maus tratos. Em razão desta decisão, os acolheram e acabaram transformando-se em pais/mães daqueles de quem cuidavam, construindo, assim, novas relações de parentesco.

Durante grande período de tempo, essas pessoas, na qualidade de responsáveis pelas crianças e adolescentes, não tiveram a preocupação em legalizar a situação, posto que isso não se colocasse como uma questão. Pode-se supor que isso se deva, nos termos de Edward e Strathern, (2000 p. 149), ao fato de essas crianças serem concebidas como dádivas e pensadas como propriedade das diversas famílias nas quais circulam. Por esse motivo, não haveria razão para propositura de ações de cunho legal para regularizar as relações de propriedade.

Apesar disso, dentre o material pesquisado encontrei muitas ações visando à regularização de uma "guarda de fato" e a mutação desta para uma parentalidade "de direito". Talvez isso tenha ocorrido menos por vontade de "pais de fato" de transformarem-se em "pais de direito" e mais em razão de demandas decorrentes da necessidade de "regularizar o registro escolar", de "emitir documentação", "do receio de que a mãe de nascimento retorne para buscar a criança", "da vontade dos irmãos de ter o mesmo sobrenome". 
De forma exemplar, há a ação de adoção cumulada com destituição de poder familiar ${ }^{26}$, aberta por Joaquim e Conceição. De acordo com a peça inicial proposta pelo advogado do casal, "os requerentes são casados há 2 anos, mas vivem juntos há 5 . Não têm filhos em comum, mas possuem filhos de suas uniões anteriores". Ao serem escutados pela equipe técnica, "informam que cuidam da criança requerida desde o seu nascimento e que a genitora possui mais dois filhos, todos em situação de abandono e desleixo, e que por este motivo vêm pleitear o pedido". Em contraposição, a mãe de nascimento, de acordo com seu defensor, "contestou a inicial e alegou que nunca abandonou a criança e que inclusive a visitava e que só deixou a filha com a requerente por que não tinha condições financeiras necessárias para criá-la e que não quer que a mesma seja colocada em adoção".

O casal requerente, ao falar do que enseja a ação, busca positivar suas decisões por meio de um cálculo de repercussão (VIANNA, 2002), ressaltando que "sempre cuidaram da menina, abandonada por Maria, [a mãe de nascimento]". Maria, por sua vez, pela voz de seu defensor, procura realçar para os agentes da justiça que não "abandou" a filha, mas, antes, "a deixou sob os cuidados da família por dificuldades financeiras”. À luz de considerações feitas por Vianna (2002), é possível apreender que a noção de "abandono" é passível de contestações e de reordenações de significados dependendo das configurações morais das pessoas a quem este termo se refere.

A regularização de uma guarda de fato por meio de uma proposição de adoção não ocorre somente nas situações antes descritas. De acordo com o material pesquisado essas ações podem ser movidas também quando pessoas ou casais que desejaram ter filhos por via reprodutiva não conseguiram. Após tentarem a adoção através da Justiça da Infância e da Juventude, ao lidarem com a "burocracia", com a "demora" processual, resolvem ir à busca de pessoas capazes de intermediar a relação com pais e mães que desejavam "doar"

\footnotetext{
${ }^{26}$ Segundo Rossato (2012), trata-se de pedido "que somente será analisado se o relativo à destituição do poder familiar puder ser acolhido" (2012, p. 437). Nestes casos, a destituição, requerida em sua maioria pelo Ministério Público, é realizada em "caráter liminar". Tratam-se de situações em que o processo de destituição de poder familiar ocorre simultaneamente com o processo de adoção, para que o procedimento ocorra de maneira rápida e evite trâmites burocráticos demorados.
} 
os seus filhos, sobretudo recém-nascidos. De posse da criança, após um lapso de tempo ajuízam a ação com a intenção de regularizar a situação, que, segundo alguns argumentos produzidos nesse tipo de processo, já se encontra pautada em "afeto, cuidado e reconhecimento da parentalidade pela criança".

Apesar de a legislação sobre adoção estar suportada na premissa de que toda a trajetória adotiva deva ser regulada pelo Poder Judiciário, de forma a "evitar que o dinheiro atravesse as obrigações morais e afetivas constitutivas das relações de parentesco (CIORDA e RUSSO, 2013, p. 463)”, esse dispositivo não impede que os requerentes se movimentem para além dessa esfera. Dessa forma, ao mesmo tempo em que seguem os ordenamentos jurídicos, procurando as Varas da Infância e da Juventude, realizando o procedimento legal de adoção, agem às margens dos poderes de Estado ${ }^{27}$ (DAS; POOLE, 2008), misturando práticas legais e ilegais. De forma exemplar, é possível citar a ação de adoção proposta pelo casal Breno e Marilaine. De acordo com a inicial escrita pelo advogado dos requentes:

Os requerentes são casados [há mais de dez anos]. Deste casamento não adveio filhos (sic). Nos últimos três anos, o casal vem tentando, por tratamento médico e inclusive por inseminação artificial, a tão esperada gravidez, mostrando-se infrutíferos tais procedimentos. Desta forma, a partir do início de xxx, o casal vem se habilitando em diversas comarcas para o procedimento de adoção. Nesta comarca do Rio de Janeiro, inclusive, o procedimento de habilitação já foi finalizado, estando os requerentes habilitados para adoção na forma da declaração de aptidão para adoção [...].

De acordo com essa mesma peça processual, o casal "soube do nascimento da menor $G$ na cidade de Fortaleza e de que sua mãe biológica. não tinha condições de criá-la [...] tendo esta resolvido oferecer a recém-nasci-

\footnotetext{
${ }_{27}$ Das e Poole (2008) consideram "margens do Estado": "El primer enfoque dio prioridad a la idea de margen como periferia em donde están contenidas aquellas personas que se consideran insuficientemente socializadas en los marcos de la ley" [...] Un segundo enfoque relacionado con el concepto de margen [...] gira en torno a los temas de legibilidad e ilegibilidad Reconocemos que las prácticas de relevamiento documental y estadísticodel estado están al servicio de la consolidación del control estatal sobre lossujetos, las poblaciones, los territorios y las vidas. [...] Un tercer enfoque se concentra en el margen como el espacio entre loscuerpos, la ley y la disciplina” (2008, p. 24-25).
} 
da para adoção" (grifo meu). O que demonstra o movimento de busca de informações com intermediários sobre mulheres que desejavam "doar" seus filhos, apesar disso estar atenuado na escrita do advogado, que ressalta não só que a mãe de nascimento "entregou a adotanda para os requerentes há um ano por não ter condições financeiras de criá-la", mas que "concedeu aos requerentes a autorização para viagem da menor G por documento firmado em Cartório de Registro Civil". Vale ressaltar que essa "autorização firmada em cartório" não possui valor legal quando se trata de guarda de infante, posto que esse procedimento deve ser realizado na esfera da Justiça da Infância e da Juventude.

\section{ABANDONO, CUIDADO, PERPETUAÇÃO E NOMEAÇÃO}

Nos documentos analisados, como dito antes, emergem visões pelas quais as relações de parentesco são compreendidas não só como produto dos laços de "sangue", mas como resultado do cuidado, da criação, do reconhecimento e do afeto proveniente do convívio social entre pessoas (cf. SCHNEIDER, 1980).

À luz dessa visão encontrei ações de adoção unilateral - ações propostas pelo/a companheiro/a da mãe ou do pai, no exercício da "função parental" sendo ajuizadas com o argumento de que tais proposições decorrem de relações de parentalidade e de filiação consolidadas ao longo da convivência familiar. Sendo assim, esses requerimentos adotivos levam a pensar, parafraseando Janet Carsten (2007, p. 405), que parte da população envolvida nos processos compreende as conexões de parentesco não só como produto do conhecimento sobre as origens biogenéticas, mas como resultado de experiências de vida e de produção de memórias afetivas.

Por esse motivo, companheiros das mães de nascimento constroem nos "autos" como motivo da proposição o fato de que, apesar de a criança ou adolescente ter um "pai de fato", a função paterna sempre foi desempenhada por ele. Nestes casos, intenciona-se que a paternidade fisiológica perca valor em 
face aos supostos laços afetivos, construídos ao longo da convivência familiar. De forma exemplar, tais argumentos podem ser vistos na peça inicial escrita pelo advogado do requerente Rafael, casado com Maria Lúcia, com o intuito de perfilhar Rodrigo, filho de sua esposa, com a qual vive há doze anos. Objetivando provar para os técnicos da Justiça da Infância e da Juventude o motivo do pleito, narra para esses profissionais "que conheceu o menino com 5 anos e que sempre desempenhou junto ao mesmo a função paterna". Segundo o advogado do requerente:

O adotando possui 17 anos e sua mãe mora com o requerente há 12 anos. O genitor do menino não presta qualquer assistência ao menor, desde que este tinha apenas 2 meses de idade. A genitora ingressou com ação de alimentos em face do genitor, sendo que este jamais pagou qualquer quantia, tendo ainda pedido demissão do emprego para não pagar a pensão. $\mathrm{O}$ menino não mantém contato com a família do genitor, tendo sido dito pela avó paterna que não queria laços entre pai e filho para que o genitor não tivesse que pagar pensão alimentícia. $O$ requerente é padrasto do menino e vem prestando-lhe toda assistência moral, material e educacional, atribuindo-lhe ainda, condição de filho, desde quando bebê. [...] O menino tem afeto de filho em relação ao requerente, sendo este a única figura paterna que conhece, vez que seu pai biológico nunca o procurou (grifo no original).

Nota-se, portanto, por parte do advogado que representa Rafael, não só a intenção de "provar a paternidade", mas a produção do "abandono" do pai de nascimento. À luz do que Vianna (2002) ressalta em seu trabalho sobre as dimensões tutelares da gestão da infância contemporânea, as verdades contidas em um processo envolvendo guarda, adoção e/ou destituição de poder familiar podem ser objetos construtores de novas realidades.

Dito de outra forma, conforme Rinaldi (2015), os agentes do Direito envolvidos nesses processos não agem apenas disciplinando e normatizando os litigantes por meio de valores universais/dominantes. Nesse sentido, a moralidade construída pelos envolvidos, em seus depoimentos, é capaz de afetar os rumos do processo. Os contornos, criados por vítimas e acusados, do que seria o moralmente intolerável a ponto de justificar uma destituição de poder 
de uma família e consequente adoção, poderiam ser, por vezes, incorporados pelos profissionais do Direito.

Acredito, ainda, que a narrativa de Rafael e de seu advogado possibilitou que o requerente fosse interpretado não só como um "bom e verdadeiro pai", mas fez com que o pai de nascimento e seus familiares fossem compreendidos como pessoas incapazes de doar "alimentos e afetos". Por esse percurso, nos trâmites da prática da Justiça da Infância e da Juventude, o padrasto pôde ser tornado pai.

A gramática moral de cunho caritativa organiza um possível sentido para a adoção. O compromisso social de cuidar de crianças necessitadas, juntamente do desejo desinteressado de ter filhos adotivos, leva também algumas pessoas às VIJI. Como pode ser visto em trecho do relatório psicossocial da ação de habilitação proposta por Daniel e Ligia, respectivamente um vendedor e uma radiologista. Ambos com mais de quarenta anos, tiveram quatro filhos ao longo da vida conjugal e um deles foi por adoção. Além dessa, o casal deseja ter mais uma criança por via adotiva. Sobre as razões dessa busca, Ligia afirma, por meio do relatório produzido pela equipe técnica da Vara, que:

O desejo de adotar uma criança sempre foi discurso presente entre o casal desde o início do namoro. Ela conta que, antes mesmo de conhecê-lo já avisava a todos que no futuro adotaria uma criança $A$ requerente diz que queria ter irmãos [...] Desde pequena comentava com sua mãe sobre o seu desejo de adotar crianças [...] Sua ligação com questões sociais é marca de sua subjetividade. Trabalha na casa espírita em XXX onde existe um abrigo de meninas. Lá se apaixona pelas crianças e toma o cuidado de não levá-las para casa.

Neste caso, nota-se que, além de questões de ordem caritativa, são trazidas para a construção do motivo a vontade de aumentar a família, uma vez que o casal já possuía filhos, e o desejo de exercer a paternidade/maternidade por meio da adoção.

A partir da análise dos procedimentos de habilitação, pude notar que o fato de um dos cônjuges ter vivido em uma família com histórias ligadas à adoção faz que a aproximação com a temática seja transformada em projeto de fi- 
liação do casal. Como exemplo, há o caso de Vitória, técnica administrativa, casada com Jairo, comerciante. Ela já possuía filhos do primeiro casamento; ele não possuía nenhum descendente; e juntos tiveram um projeto parental por meio da adoção. Ambos tinham mais de 50 anos e não conseguiram a reprodução "natural". Uma vez que Vitória fora criada em uma "família substituta" e nunca tivera contato com seus "pais biológicos", desejou que seu outro filho viesse por meio da adoção. Tornou, assim, a sua vontade em um projeto familiar. É possível supor que Vitória vislumbre que o encontro com o filho desejado não seja apenas a concretização do projeto parental, mas a possibilidade de retribuir a dádiva (MAUSS, 1988) recebida de sua família da qual recebeu cuidados, doando afeto e cuidado ao filho que chegar a sua casa.

A partir das habilitações, notei que pessoas solteiras sem filhos, de diferentes orientações sexuais, procuram o Judiciário com o intuito de se tornarem pais e mães dentro ou fora da esfera conjugal ${ }^{28}$. Além destas, viúvos e divorciados sem prole e outros que já viveram a experiência da paternidade e maternidade em casamentos anteriores, desejando vivê-la sozinhos procuram as VIJI. Como exemplo, há a história de Fernando, um rapaz que, segundo o estudo psicológico, "sempre teve desejo de ter filhos, mas como não se casou, nem conseguiu firmar um relacionamento sólido com alguém, a tão desejada filiação acabou não acontecendo". Desta maneira, a adoção surge como caminho para a realização do desejo de exercer a paternidade inviabilizada biologicamente.

É como se, desta filiação, pudesse surgir a possibilidade de continuidade e reprodução do nome da família. Seguindo as reflexões de Pina Cabral $(1993,2005)$, garantir que uma pessoa tenha o mesmo sobrenome de família significa a consolidação de laços através da legalização de relações fáticas de parentesco. Além disso, a aquisição do nome de família produz efeitos simbólicos e práticos de prolongamento de conexões (CARSTEN, 2007) entre pessoas para além de suas vidas, uma vez que permite que aquele que o adquiriu o transmita aos seus descendentes, garantindo a perpetuação de vínculos e de direitos.

\footnotetext{
${ }_{28}$ Segundo Uziel, em pesquisa sobre homossexualidade e adoção, "o casamento e o desejo de partilhar a vida a dois (nos dias atuais, em nossa sociedade) deixam de ser condições únicas para as pessoas tornarem-se pais e mães" (UZIEL, 2007, p. 33).
} 
Há os que consideram a adoção como preenchimento do "vazio da vida". Este é o caso de Dalva, divorciada, com filhos adultos e que, além de querer "ajudar uma criança necessitada", busca alguém para lhe fazer companhia. Como exposto no trecho do relatório psicossocial,

A requerente já no grupo de habilitação apresentava uma postura diferente daquela que se espera de uma futura candidata à adoção de uma criança, pois se referia ao filho como a criança que irá preencher o vazio da casa, fazendo-lhe companhia, já que os filhos já têm vida própria. Também coloca o desejo, que nos pareceu sincero, de ajudar uma criança, "tirando-a da rua", onde na maioria das situações se encontra à mercê da própria sorte.

Tal posicionamento, segundo a visão da equipe técnica, leva ao indeferimento do pedido porque não "contempla, de forma satisfatória, a filiação adotiva”. Dito de outra forma, aos olhos do Poder Judiciário, a requerente não procura "um filho desejado" e não se coloca como sua futura mãe. A sua motivação é interpretada como uma ação de cunho filantrópico, o que, aos olhos dos psicólogos e assistentes sociais, inviabilizaria o sentimento de pertencimento ao espaço sociofamiliar, fundamental para construção de uma identidade filial.

Os membros da equipe técnica da Vara da Infância da Juventude e do Idoso organizam suas práticas a partir de uma economia moral (FASSIN, 2014) 29 suportada na ideia de que a filiação por adoção não pode ocorrer em face de uma vontade de fazer caridade, nem por motivos "inconscientes" que não dizem respeito a um projeto filial. No decorrer das incursões em campo, foi possível ver assistentes sociais, psicólogos e advogados, ao palestrarem em grupos de apoio à adoção, dizerem que "adoção não é caridade", mas um "ato egoísta" por ser a concretização do desejo de filiação. Além disso, alguns diziam que a busca pela filiação substituta não deve ocorrer para sanar "faltas" decorrentes do processo de constituição psíquica dos sujeitos.

\footnotetext{
${ }^{29}$ De acordo com Didier Fassin (2014), uma economia moral significa o escopo de valores e normas morais de um dado grupo em um dado momento que definem o âmbito de uma biopolítica. Dito de outra forma, diz respeito aos valores mobilizados nas práticas estatais para gerir os fluxos humanos.
} 


\section{CONSIDERAÇÕES FINAIS}

Ao iniciar a pesquisa, buscava compreender o que move pessoas e casais a um projeto parental por via da adoção. Pressupunha que uma ação desse tipo era movida em função de um imperativo da reprodução. Ou seja, considerava que pais adotivos e "pretendentes" buscavam-na como "saída" para um projeto parental "biológico-natural" sem sucesso.

Sem perceber, partia de um modelo hegemônico de família de camadas médias centrada em uma unidade doméstica composta por um pai, uma mãe e uma prole (existente ou desejada). Além disso, impactada pelo discurso produzido pelos agentes produtores e reprodutores das políticas de adoção, considerava que a busca por essa forma de filiação e o sentido a ela atribuído estava vinculada à concretização de um projeto parental conjugal.

Entretanto, ao longo dessa trajetória analítica pude perceber que os adotantes elaboram sentidos múltiplos sobre essa filiação. A adoção é formulada como a realização de desejo de filiação; como uma estratégia de manutenção/criação de elos familiares em contexto de um novo arranjo familiar; como uma maneira de fugir dos imperativos da natureza, criando formas de ter filhos sem engravidar. É, também, vista como uma forma de retribuir cuidados recebidos e como um caminho para perpetuar o nome de família e do patrimônio construído.

Tratam-se de sentidos diversos que não se restringem aos valores das famílias de camadas médias, tampouco poderiam ser explicados como exclusivos das camadas populares. Fazer tal afirmativa não significa desconsiderar as especificidades dos grupos locais, mas antes representa um esforço analítico que consiste em ressaltar o peso mais amplo das conexões de parentesco e seus efeitos sobre as trajetórias das pessoas. Seguindo a pista de Fonseca (2002), essa analítica permite ultrapassar a tentação de formular um modelo de família e, baseado nesse, abordar as práticas diversas.

Quanto aos ideais adotivos formulados pelas políticas da Justiça da Infância e da Juventude, vale ressaltar que estão distantes dos sentidos elencados pelo público pesquisado. Apesar disso tratam-se de demandas que são em 
sua maioria acatadas pelos profissionais das Varas da Infância e da Juventude. Assim posto, isso leva à consideração de não só que os sentidos adotivos são múltiplos, mas também que nos processos dessa ordem os agentes do direito não atuam exclusivamente disciplinando os demandantes à luz do que consideram um ideal. Esses profissionais são afetados por moralidades, por dores, por sentidos formulados pelos requerentes sobre as razões que ensejam a filiação "socioafetiva".

\section{REFERÊNCIAS}

1. ABREU, Domingos. No bico da cegonha: histórias de adoção e da adoção internacional no Brasil. Rio de Janeiro: Relume Dumará, 2002.

2. BITTENCOURT, Sávio. A nova Lei de Adoção. Do abandono à Garantia do Direito à Convivência Familiar e Comunitária. Rio de Janeiro: LumenJuris Editora, 2010.

3. CARSTEN, Janet. Cultures of Relatedness: new approaches to de study of kinship. London: Cambridge University Press, 2000.

4. CARSTEN, Janet. A matéria do parentesco. Revista de Antropologia da UFSCAR, v. 6, n. 2, p. 103-118, 2014.

5. CARSTEN, Janet. Constitutive Knowledge: Tracing Trajectories of Information in New Contexts of Relatedness. Project Muse. Scholarly Journals online, v. 80, n. 2, p. 403-426, 2007.

6. CIORDIA, Carolina; RUSSO, Marlene Denise. La gestión de los afectos. Administración judicial de conflictos familiares en los tribunales de família. Intersecciones en Antropología, v. 15, n. 2, p. 461-472, 2014.

7. EDWARDS, Jeanette; STRATHERN, Marilyn. Including our own. In: CARSTEN, Janet. Cultures of Relatedness: new approaches to de study of kinship. London: Cambridge University Press, 2000.

8. FASSIN, Didier. Compaixão e repressão: a economia moral das políticas de imigração na França. PontoUrbe, n. 15, p. 2-22, 2014.

9. FONSECA, Claudia. Abandono, adoção e anonimato: questões de moralidade materna suscitadas pelas propostas legais de "parto anônimo". Sexualidad, Salud y Sociedad - Revista Lationoamericana, n. 1, p. 30-62, 2009. 
10. FONSECA, Claudia. O abandono da razão: a descolonização dos discursos sobre a infância e a família. In: SOUZA, André Luiz (Org.) Psicanálise e colonização: leituras do sintoma social no Brasil. Porto Alegre: Artes Médicas, 1999.

11. FONSECA, Claudia. Criança, família e desigualdade racial no Brasil. In: RIZZINI, Irene. A criança no Brasil hoje: desafios para o terceiro milênio. Rio de Janeiro: Editora Universitária Santa Úrsula, 1993.

12. FONSECA, Claudia. A vingança de Capitu: DNA, escolha e destino na família brasileira contemporânea. In: BRUSCHINI, Cristina; UNBEHAUM, Sandra G. (Org.). Gênero, democracia e sociedade brasileira. São Paulo: Fundação Carlos Chagas/ Edições 34, 2002, p. 267-95.

13. FONSECA, Claudia. Lucro, cuidado e parentesco. Civitas, Porto Alegre, v. 13, n. 2, p. 269-291, 2013.

14. FONSECA, Claudia. A certeza que pariu a dúvida: paternidade e DNA. Revista Estudos Feministas, Rio de Janeiro, v. 12, n. 2, p. 13-34, 2004.

15. FONSECA, Claudia. Os caminhos da adoção. São Paulo: Cortes, 1995.

16. FRANKLIN, Sarah. Biologization revisited: kinship theory in the context of the new biologies. In: FRANKLIN, Sarah; MCKINNON, Susan (Ed.). Relative values. Duke University Press, 2001.

17. LUNA, Naara. Natureza humana criada em laboratório: biologização e genetização do parentesco nas novas tecnologias reprodutivas. História, Ciências, Saúde, v. 12, n. 2, p. 395-417, 2005.

18. MUZZOPAPPA, Eva; VILLALTA, Carla. Los documentos como campo: reflexiones teórico-metodológicas sobre un enfoque etnográfico de archivos y documentos estatales. Revista Colombiana de Antropología, v. 47, n. 1, p. 13-42, 2011.

19. MOURA, Daniele Gomes. Do abandono afetivo à adoção unilateral: respostas jurídicas à alienação parental. Dissertação (Mestrado em Direito), PPGD, Universidade Estácio de Sá, Rio de Janeiro, 2011.

20. NUNES, Marcelo Guedes. Tempo dos processos relacionados à adoção no Brasil. Uma análise sobre os impactos da atuação do Poder Judiciário. São Paulo: ABJ, 2015.

21. OUELLETTE, Françoise-Romaine. Parenté et adoption. Sociétés Contemporaines, n. 38, p. 49-65, 2000.

22. PINA CABRAL, João. A lei e a paternidade: as leis de filiação portuguesas vistas à luz da antropologia social. Análise Social, v. xxviii, p. 975-997, 1993. 
23. PINA CABRAL, João. O limiar dos afetos: algumas considerações sobre nomeação e a constituição social de pessoas. Aula inaugural do Programa de Pós-Graduação em Antropologia Social da Unicamp, São Paulo, abril de 2005.

24. PINA CABRAL, João; LIMA, Antónia P. Como fazer uma história de família: um exercício de contextualização social. Etnográfica, v. IX, n. 2, p. 355-388, 2005.

25. RINALDI, Alessandra de Andrade. A nova cultura da adoção o papel pedagógico dos Grupos de Apoio à Adoção no município do Rio de Janeiro. Jurispoiesis, Rio de Janeiro, v. 13, p. 13-37, 2010.

26. RINALDI, Alessandra de Andrade. A arte de lutar contra a natureza: motivos que movem a adoção no município do Rio de Janeiro. In: LADVOCAT, Cynthia; DIUANA, Solange. (Org.). Guia de adoção: no jurídico, no social, no psicológico e na família. 1. ed. São Paulo: Roca, 2014.

27. RINALDI, Alessandra de Andrade. A sexualização do crime no Brasil: um estudo sobre criminalidade feminina em contexto de relações amorosas (1890-1940). Rio de Janeiro: FAPERJ/MAUD X, 2015.

28. SILVA, Milena Leite; ARPINI, Dorian Mônica. A nova Lei Nacional de Adoção - desafios para a reinserção familiar. Psicologia em Estudo, Maringá, v. 18, p. 125-135, 2013.

29. SCHNEIDER, David. American Kinship: a cultural account. Chicago: University of Chicago Press, 1980.

30. SCHUCH, Patrice. Práticas de justiça: Antropologia dos modos de governo da infância e juventude no contexto pós-ECA. Porto Alegre: Editora da UFRGS, 2009.

31. SCHUCH, Patrice. Políticas de proteção à infância: um olhar antropológico. Porto Alegre: Editora da UFRGS, 2009a.

32. SCHUCH, Patrice. Como a família funciona em políticas de intervenção social. Civitas, Porto Alegre, v. 13, n. 2, p. 309-325, maio-ago. 2013.

33. STRATHERN, Marilyn. Displacing knowledge: technology and the consequences for kinship. In: GINSBURG, Faye G.; RAPP, Rayna (Ed.) Conceiving the new world order. Berkeley/Los Angeles/London: University of California Press, 1995, p. 323-45.

34. STRATHERN, Marilyn. Parentesco, Direito e o inesperado. Parentes são sempre uma surpresa. São Paulo. Editora da UNESP, 2015.

35. STRATHERN, Marilyn. Necessidade de pais, necessidade de mães. Estudos Feministas, v. 3, n. 2, p. 303-329, 1995. 
36. VIANNA, Adriana de Resende Barreto. Limites da menoridade: tutela, família e autoridade em julgamento. 350f. Tese (Doutorado em Antropologia Social), PPGAS, Museu Nacional, Universidade Federal do Rio de Janeiro, Rio de Janeiro, 2002.

37. YNGVESSON, Barbara. Parentesco reconfigurado no espaço da adoção. Cadernos Pagu, v. 29, jul-dez 2007.

38. UZIEL, Ana Paula. Homossexualidade e adoção. Rio de Janeiro: Garamond, 2007.

\section{Acórdãos, resoluções, códigos e legislações}

1. BRASIL. Lei $\mathbf{n}^{\circ} \mathbf{8 . 0 6 9}$, de 13 de julho de 1990. AMPERJ Legislação. Estatuto da Criança e do Adolescente. Dispõe sobre o Estatuto da Criança e do Adolescente, e dá outras providências.

BRASIL. Lei no 12.010, de 29 de julho de 2009. Disponível em: http://www.jusbrasil.com.br/legislacao/818490/lei-12010-09. Acesso em: 5 out. 2010.

2. BRASIL. Lei $\mathbf{n}^{\mathbf{0}} \mathbf{1 3 . 5 0 9}$, de 22 de novembro de 2017. Disponível em: http://www. planalto.gov.br/ccivil_03/_ato2015-2018/2017/lei/L13509.htm. Acesso em: 5 mar.2018

\section{Sites}

1. IBDFAM. História. Disponível em: http://bit.ly/2EP8MNg. Acesso em: 5 jun. 2018.

2. Terra dos Homens. Cuidar de quem cuida. Disponível em: http://bit.ly/2RquhuQ. Acesso em: 4 mai. 2018.

3. IBDFAM. Série “Um olhar sobre a adoção". Disponível em: http://bit.ly/2Ro6xHu. Acesso em: 12 jun. 2018.

4. Associação Brasileira de Jurimetria. Tempo dos processos relacionados à adoção no Brasil - uma análise sobre os impactos da atuação do poder judiciário. Disponível em: http://bit.ly/2QVr5rD. Acesso em: 12 jul. 2018. 